\title{
Do brand relationships on social media motivate young consumers' value co-creation and willingness to pay? The role of brand love
}

\author{
Elaine Wallace \\ J. E. Cairnes School of Business \& Economics, National University of Ireland Galway, \\ Galway, Ireland \\ Email: elaine.wallace@nuigalway.ie \\ Pedro Torres * \\ University of Coimbra, CeBER, Faculty of Economics \\ Portugal \\ E-mail: pedro.torres@uc.pt \\ Mário Augusto \\ University of Coimbra, CeBER, Faculty of Economics \\ Portugal \\ E-mail: maugusto@fe.uc.pt \\ Maryana Stefuryn \\ University of Coimbra, Faculty of Economics \\ Portugal \\ E-mail: maryana1794@gmail.com
}

The final version of this article is available online at https://www.emeraldinsight.com/doi/pdfplus/[https://doi.org/10.1108/JPBM-06-20202937]

This manuscript version is made available under the under the Creative Commons Attribution Non-commercial International Licence 4.0 (CC BY-NC 4.0). Reuse is allowed in accordance with the terms outlined by this licence.

* Corresponding Author

Funding : This work has been funded by national funds through FCT - Fundação para a Ciência e a Tecnologia, I.P., Project UIDB/05037/2020 


\title{
Do brand relationships on social media motivate young consumers' value co-creation and willingness to pay? The role of brand love
}

\begin{abstract}
Purpose: Drawing on consumer brand relationship theory, the study investigates online brand engagement, brand trust, and consumer brand identification as antecedents of brand love, among Generation $\mathrm{Y}$ and $\mathrm{Z}$ consumers. It explores the role of brand love in predicting consumers' intention to co-create value and willingness to pay a premium price for the brand, for brands followed on social media.

Design/methodology/approach: Data from a study of 332 followers of brands on social media was analysed using structural equation modeling.

Findings: Results highlight the role of brand love in mediating the relationship between antecedents online brand engagement and consumer brand identification on intention to co-create value and willingness to pay a premium price. Consumers who trust the brand are more likely to intend to co-create value and are more willing to pay a price premium, and these relationships are enhanced when the brand is loved.

Practical implications: Findings provide guidance for managers seeking to build brand friendship relationships with young consumers through social media. Results caution against a form of 'superficial' friendship where the consumer may interact and co-create value online, yet fail to value the brand, evidenced through willingness to pay a premium price.
\end{abstract}

Originality/value: The research identifies the critical role of brand love in fostering relationships with brands that young consumers follow on social media. The study reveals that neither online brand engagement nor consumer brand identification will result in co-creation of value or willingness to pay a premium price unless the consumer experiences brand love.

Classification: Research Paper

Keywords: Brand love, Online Brand Engagement, Brand Trust, Online Consumer Brand Identification, Intention to Co-Create Value, Willingness to Pay a Premium Price. 


\section{Introduction}

Building on the extant theory which considers the relationship that customers have with a brand (Fournier, 1998), this study investigates online brand engagement, brand trust, and consumer brand identification as antecedents of brand love, among Generation Y and $\mathrm{Z}$ consumers. It explores the role of brand love in predicting consumers' intention to cocreate value and willingness to pay a premium price for the brand. As social media use is associated with brand relationship quality (Hudson et al., 2016), extant studies have emphasised the need for better understanding of the role of brand love for brand outcomes in a social media context (Machado et al., 2019).

On social media, brand love is stimulated as a reflection of the consumer's brand response, for example through the 'Like' button on Facebook or the heart icon on Instagram (Machado et al., 2019). The current study investigates brand love among those who follow brands on social media, for example by clicking 'Like'. This is a relevant research topic since many firms are developing marketing campaigns to increase the number of 'Likes' and use it as an indicator of the consumer-brand relationship. Indeed, a recent Google search (March 2021) for 'company increase Likes on social media' revealed almost 60 million results, with advice for 'how to get more Facebook Likes' and even 'is it ever OK to buy social media Likes for your business?'. As an example, companies host Facebook contests for their followers, and these contests attention and increases Likes (hootsuite.com). Moreover, the number of Likes received on Facebook pages is often reported in companies' annual reports and the intention to implement iniatives to further grow the base of followers is explicit in some corporate documents (see for example Pandora's 2018 Annual Report, p. 26).

The marketing literature recognises that 'Likes' are useful proxy measures to quantify brand outcomes from even small-scale investment in social media marketing 
(Hoffman and Fodor, 2010). Yet research also acknowledges that mechanisms such as the 'Like' button are one-click, lightweight feedback cues (Hayes et al., 2016), requiring little effort on the consumers part, and there is debate regarding the relationship between 'Likes' and offline brand outcomes (Wallace et al., 2014). Do consumers love what they 'Like'?

Research about consumers' relationships with brands has been gaining attention from both academics and practitioners (Fetscherin et al., 2019). Academic discussion has informed much research, leading to, for example three special issues of leading academic journals on the topic, building on Fournier's (1998) seminal work, which investigated the relationship proposition in the consumer-brand context, characterised the nature of consumer-brand relationships, and proposed a diagnostic tool for evaluating the strength of those relationships. One critical point raised by Fetscherin et al. (2019) is that although consumers may have positive feelings about a brand, they may not be likely to engage with them, or form a relationship with them. Compounding this, when consumers' interactions with brands are online, these interactions may not reflect the consumer's material reality (Schau and Gilly, 2003), and online interactions with brands may not result in positive outcomes for the brand (Wallace et al., 2014).

Drawing on these important ideas, this study investigates the relationship between the consumer's online interactions with a brand, and offline brand outcomes. Indeed, these relationships can grow to a level where consumers form passionate emotional attachment to brands, which is characterised as brand love (Veloutsou and Moutinho, 2009). Brand love is 'the degree of passionate attachment a satisfied consumer has for a particular trade name (Carroll and Ahuvia, 2006 p.81). Brand love has a stronger affective focus than satisfaction, and is oftentimes the consequence of a long-term brand 
relationship (Carroll and Ahuvia, 2006). Brand love is also an important dimension of brand relationship quality (Hudson et al., 2016).

To date, although facilitation of self-expression (Wallace et al., 2014; Carroll and Ahuvia, 2006), enhancement of self-identify (Vernuccio et al., 2015), or the hedonic nature of the brand itself (Carroll and Ahuvia, 2006) have been identified as antecedents of brand love, few studies have investigated the impact of consumer relationships with the brand on brand love, or on the outcomes of brand love (Machado et al., 2019). This study investigates brand love as a central construct in a model which proposes brand trust and online brand engagement as antecedents, and the outcomes intention to co-create value and willingness to pay a premium price.

In particular, the study specifically focuses on the Generation $\mathrm{Y}$ and $\mathrm{Z}$ consumers who are active on social media. In this study, generation $\mathrm{Y}$ corresponds to those aged from 23-37 years in 2020, and Generation Z to those aged up to 22 years in 2020. Studies of these age cohorts are relevant to the study of brands on social media, as they reflect the global demographics of social media such as Instagram (Statista, 2021). Moreover, consumers who follow brand pages on social media tend to skew younger than the typical user (Lipsman et al., 2012). One reason for this is because, unlike the 'real' world, consumers are not required to own brands in order to engage with them on social media, and those brands may be outside of their material realities (Schau and Gilly, 2003). Therefore, this study investigates the attitudes of those Generation $\mathrm{Y}$ and $\mathrm{Z}$ consumers who are active on social media. It investigates whether their interactions with brands on social media enhance brand love, and whether brand love results in positive offline outcomes for that brand.

By investigating these relationships, this study identifies the critical role of brand love in fostering sustainable relationships with brands that young consumers follow on 
social media, focusing on their intention to co-create value (ICC), and their willingness to pay a premium price (WPP). We show that brand love is important for achieving these brand outcomes. Findings highlight the importance of brand trust in predicting brand love, and ICC and WPP. Therefore, the paper offers an important contribution as we provide new insights into the role of brand love.

for brands followed on social media, specifically for the outcomes ICC and WPP. We also provide new insights into brand trust, online brand engagement, and online brand identification as antecedents of brand love, for brands followed on social media.

\section{Theoretical background and hypotheses}

\subsection{Brand relationships, social media and the role of brand love}

Research about consumers' relationships with brands has been receiving attention from academics and practitioners since early work by academics such as Fournier (1998), who established the relevancy of the brand relationship theory-building goal. Framed by the consumer-brand relationship theory (Fournier, 1998), brands are considered relationship builders and relationship facilitators (Veloutsou, 2009). It is long recognised that such positive relationships with brands will lead to outcomes such as brand acceptance and WOM (Wallace et al., 2014). Positive passionate relationships with brands are referred to as brand love (Carroll and Ahuvia, 2006; Batra et al., 2012), and brand love has motivated numerous studies (e.g., Schmid and Huber, 2019; Algharabat, 2017; Bagozzi et al., 2017; Kaufmann et al., 2016; Vernuccio et al., 2015, Albert and Merunka, 2013; Bergkvist and Bech-Larsen, 2010). Carroll and Ahuvia (2006) explain that brand love has a greater affective component than satisfaction, it is conceptually distinct from mere liking, and it also precludes negative feelings such as dislike, or hate. 
More recently, Schmid and Huber (2019) asserted that brand love is the most intense connection between consumers and brands, and some research indicates that the emotions induced by brand love exceed those evoked by close friends (Langner et al., 2015). Moreover, brand love can lead to positive outcomes in the same way as those evoked by close friendship (Langner et al., 2015). Just like a traditional friendship, the brand love relationship can last for decades, and result in numerous affective, cognitive, and behavioural effects (Batra et al., 2012; Fournier, 1998). Love is distinct from other emotions which are mainly based on short-term temporary events, it is a long-term condition (Russell and Barrett, 1999).

In their critical review of the brand love literature, Palusuk et al. (2019) argued that brand love should be viewed as continually evolving, and called for further study of its antecedents and outcomes. With the ubiquity of social media use, brand managers have a greater opportunity to reach their customers, but the goal of creating loved brands, and harnessing social media to motivate consumer behaviours towards brands remains a challenge (Wallace et al., 2014). In spite of its importance, and the concurrent growing use of social media, the study of antecedents and outcomes of brand love in digital settings has been scarce. We address this relevant gap because future consumer marketing will be carried in this digital environment (Stephen, 2016) and social media marketing is a critical element of $21^{\text {st }}$ century business (Felix et al., 2017), but marketers have struggled to nurture relationships with their consumers through social media (Fournier and Avery, 2011).

We acknowledge that one way to achieve brand relationships is to build brand communities (Muniz and O'Guinn, 2001), and research has shown that brand communities could contribute to building long-lasting relationships with consumers, both offline (Junaid et al., 2019) and online (Coelho et al., 2018). Brand Communities foster 
brand love (Coelho et al., 2018; Junaid et al., 2019, Dessart et al., 2015), and participation in brand communities may enhance affective relationships between consumers and brands (Vernuccio et al., 2015).

However, on social media, consumers who 'Like' brands are not always members of brand communities, and their interactions with brands may be more ad-hoc. Earlier we noted that 'Liking' is a very lightweight means of giving feedback (Hayes et al., 2016), and research has suggested that consumers can be 'maligned for 'liking' brands for selfexpressive reasons without any real emotional connection' (Wallace et al., 2017, p.21). Although 'Liking' a brand on social media could enhance brand love (Kudeshia et al., 2016), less is known about the aspects of consumers' relationship with the brand on social media that lead to brand love. Moreover, insights into the outcomes of brand love for individuals who 'Like' brands is more limited (Kudeshia et al., 2016). We therefore considered it important to investigate brand love in the context of those who 'Like' brands on social media.

The current research recognises the importance of building relationships with younger consumers, and investigates in particular the outcomes of fostering brand love. In the context of generating relationships with young consumers, we assert that it is important to understand how best to encourage value co-creation with them. The concept of value co-creation derives from the services marketing literature, and in particular the work of Vargo and Lusch (2004). At a behavioural level, France et al. (2018) explain that value co-creation with a brand is voluntary, active, and interactive. Extant research on co-creation dynamics has emphasised the importance of younger consumers and considered dimensions such as the consumer's social life, having fun, compatibility with the brand, communication appeal, and brand commitment as antecedents of co-creation (Kennedy and Guzmán, 2016). Roberts et al. (2014) suggested that passion informed 
altruistic motives for co-creation with firms. By contrast, strong emotion also plays a part in co-destruction, with negative well-being outcomes such as worry, anxiety and anger following a firm's failure to co-create value with customers (Smith, 2013). Further new research on co-creation following a brand transgression outlines the importance of brand love, suggesting that brand love first requires the consumer to view the brand positively, and if brand love exists, the impact of transgressions is minimised (Kennedy and Guzmán, 2020).

The current study focuses on intention to co-create on social media, where there is a high level of interactivity between networked friends and their brands, and consumers can co-produce value through exchange with the firm, and with networked others (Kozinets et al., 2010). On social networks, extant literature suggests that relationship quality positively impacts on the intention to co-create value, as customers will engage in greater co-creation when the brand offers a sense of belonging and support (Tajvidi et al., 2017). As emotional attachment to the brand is present in brand love, we explore the relationship between brand love, and the intention to co-create value for those brands.

We consider the value of brand love to the firm, by exploring brand love for online brands as an antecedent of willingness to pay a premium price. Batra et al. $(2012$, p.4) asserted that those who love brands reported "investing high levels of time, energy, and money" into those brands. Extant studies have shown that when brand love is higher, the brand is perceived to be indispensable (Langner et al. 2015), and the consumer is more likely to feel distress if they lose the brand (Batra et al., 2012). As a consequence, they are more price insensitive with respect to the brand (Albert and Merunka, 2013; Thompson et al., 2005). As the study considers brand love, we investigate whether these consumers are also willing to pay a premium price for those loved brands that they engage with on social media. Therefore, the study investigates brand love as a mediator in the 
relationship between online consumer brand engagement (OCBE), brand trust (BT), and online consumer brand identification (OCBI), and their intention to co-create brand value (ICC), and willingness to pay a premium price (WPP). We discuss the hypotheses in detail below.

\subsection{Consumer brand engagement on social media}

Consumer brand engagement has a significant role in building brand relationships with consumers (Dessart et al., 2015). It is defined as 'a psychological state that occurs by virtue of interactive, co-operative customer experiences with a focal agent/object (e.g., a brand)' (Brodie et al., 2011, p.258). More broadly, consumer engagement is a multidimensional construct (Brodie et al., 2011; Loureiro et al., 2017), with a general agreement around the three main dimensions of the construct. Mollen and Wilson (2010, p.923) describe the "bonding and impact" and "emotional congruence" involved when customers are engaged with the brand. Therefore, consumer engagement is of interest in the context of building friendships with young consumers on social media.

Online brand engagement has been defined as "a cognitive and affective commitment to an active relationship with a brand as personified by a website or other computer-mediated entities designed to communicate brand value" (Mollen and Wilson, 2010, p.923). Notably, online brand engagement incorporates cognitive processing, utility and relevance, and emotional congruence (Mollen and Wilson, 2010; Brodie et al., 2011). Extant literature has also focused on engagement within brand communities (e.g., Dessart et al., 2015). This study does not require that the consumer is a member of a brand community, or engaged with peer-to-peer networks, as even 'Liking' a brand on Facebook can be an indicator of brand engagement (Machado et al., 2019). 
Consumer engagement through social media has been gaining attention in recent years due to its influence on consumer behaviour, yet there are gaps in our understanding of its outcomes (Gómez et al., 2019). Within the context of consumer brand relationships, Park et al (2016) envision that customers who experience brand engagement develop brand love. Hudson et al. (2016) stated that consumers who engaged with brands online had stronger relationships with those brands, and research in online network-based brand communities has investigated the relationship between engagement and brand love (Vernuccio et al., 2015). However, although Vernuccio et al.'s (2015) research investigated communities on Facebook where people were member of brand fan pages, their measure of engagement focused on social-interactive engagement, whereby people interact with others in the community, rather than on engagement with the brand itself. Nevertheless, their results indicate a positive relationship between engagement and brand love. However, the relationship between brand engagement with the brand followed and brand love for the followed brand clearly warrants further investigation.

While research has considered the impact of brand engagement on social media on the quality of the consumer's relationship with the brand (Gómez et al., 2019), it has not specifically considered whether brand engagement leads to brand love. Moreover, while Wallace et al.'s (2014) study of brand fans on Facebook found that consumer engagement with a brand was associated with brand love, their study adopted 'Liking' a brand on Facebook as a proxy measure of brand engagement, rather than measuring brand engagement specifically as an antecedent of brand love. Nevertheless, their findings indicated that engagement with brands on social media (evidenced through selfexpressive brand 'Likes) was positively associated with brand love.

Machado et al. (2019) identified a positive relationship between consumer brand engagement and brand love, when the brand is a "Liked" brand on Facebook, but they 
emphasize that few studies have focused on the role of brand love in this context. Further, their study was limited to investigating the effect of gendered personality traits of the brand on $\mathrm{CBBE}$, where brand engagement and brand love mediate that relationship. We further investigate the relationship between consumer engagement with brands followed on social media and brand love, seeking to extend this insight beyond the context of Facebook, to social media more generally. Hence, we hypothesise:

\section{H1: Online consumer brand engagement is positively associated with brand love.}

Moreover, consumer brand relationship literature suggests that interaction is common with engaged consumers. That is, a two-way interaction is fostered between the engagement subject and object (Brodie et al., 2011). Brand engagement has been conceptualised as having a direct influence on customer brand co-creation behaviour (France et al., 2018). In line with Tajvidi et al. (2017, p.2), we define brand value cocreation as "co-created value through customers' engagement in specific interactive experiences and activities in relation to a certain brand, triggered by the new design features of social commerce." Extant literature suggests that initial interaction with a brand can enhance online engagement (Loureiro et al., 2017), and those consumers who experience online brand engagement will be subsequently motivated to co-create further brand value, due to their affective response to the brand and their perceptions of the brand's responsiveness to their interactions (Mollen and Wilson, 2010). However, Mollen and Wilson's (2010) conceptual study did not test the relationship between engagement and behaviour and therefore, in the context of online brand engagement, the study hypothesises:

H2: Online consumer brand engagement is positively associated with intention to co-create brand value. 
Will consumers pay more for brands that they engage with on social media? Extant research acknowledges the cognitive, affective and behavioural aspects of brand engagement (e.g., Brodie et al., 2011) and the influence of online brand engagement on behaviour (e.g., Loureiro et al., 2017; Dessart et al., 2015). Hollebeek (2011) asserted a customer's overall sense of the utility of a product or service would be a consequence of a customer's brand engagement. Although the focus of her research was brand loyalty, Hollebeek (2011) highlighted the contribution of customer brand engagement to satisfaction and value. More recently, Machado et al. (2019) identified a positive impact on consumer-based brand equity (CBBE). They acknowledge that a key component of CBBE is willingness to pay (Kim et al., 2001), and they revealed a positive relationship between consumer brand engagement on Facebook and CBBE, however they did not measure consumers' willingness to pay a premium. Indeed, to the best of our knowledge, the specific relationship between online brand equity and offline willingness to pay a premium price has not been investigated. Therefore, the following is hypothesised:

H3: Online consumer brand engagement is positively associated with willingness to pay a premium price.

\subsection{Brand trust on social media}

Brand trust is defined as "the consumer's confidence that the brand will act as expected" (Gretry et al., 2017, p.78). Trust is central to the quality of any relationship (Morgan and Hunt, 1994), and it is critical when forming relationships with consumers on social media (Gleeson, 2012). Gretry et al. (2017, p.83) describe brand trust as "a milestone in building consumer-brand relationships in social media environments". 
Developing online consumer brand trust has been considered essential in digital settings (e.g., Hajli, 2014).

The relationship between trust and love is an important one. Offline, brand love literature asserts that consumers who are 'in love' with a brand state that they have never been disappointed with the brand (Albert et al., 2008). When brand trust is low, consumers do not open up to brands, because they feel vulnerable (Schoenbachler and Gordon, 2002). By contrast, Albert et al. (2013) noted that brand trust positively influenced brand passion, an underlying dimension of brand love (Albert et al., 2008; Batra et al., 2012). In distinguishing interpersonal love from brand love, Ahuvia et al. (2012) note that while interpersonal love may be unconditional, this was not the case for brand love, and trustworthiness was considered an attractive quality associated with loved brands. In a further study of brand love in consumer-brand relationships, Albert and Merunka (2013) found that brand trust influenced brand love, and they explained that, just as in interpersonal relationships, trust in the partner determines the individual's feelings towards the partner (or brand).

As this research is focused on building relationships with consumers on social media, we included brand trust in the conceptual framework. In the current study, we investigate online brand trust as trust arising as a consequence of interacting with the brand online, in line with Laroche et al. (2012). However, their important study was focused on brand communities and they did not consider the impact of online brand trust on brand love. As studies on brand love's determinants are limited (Junaid et al., 2019), and as brand trust has been investigated as an antecedent of brand love in an offline context (Albert, 2013, Albert and Merunka, 2013) this research investigates brand trust as an antecedent of brand love, for brands followed on social media. The study hypothesises: 


\section{H4: Brand trust is positively associated with brand love.}

The extant literature on brand trust outcomes also identifies a positive relationship between brand trust and word of mouth (Albert and Merunka, 2013). We acknowledge that consumers who love a brand will be likely to 'talk up' that brand to others (Carroll and Ahuvia, 2006). We extend this research by investigating the relationship between trust and the consumer's intention to co-create value. In recent research with customers who use online brand pages, Tajvidi et al. (2017) noted that individuals who had a higher level of trust toward the brand page, would have greater intention to co-create value. However, their empirical study considered trust as a dimension of relationship quality, and they measured relationship quality overall as an antecedent of intention to co-create value. Therefore, they did not specifically investigate the relationship between trust and intention to co-create value. Furthermore, while Kennedy and Guzmán (2020) investigated the outcomes of violation of trust on brand relationships and co-creation, their empirical study did not measure trust specifically. Therefore our study seeks to add to this literature by measuring trust specifically, and by investigating the relationship between brand trust and intention to create brand value. We hypothesise:

\section{H5: Brand trust is positively associated with intention to co-create brand value.}

The study also investigates the relationship between brand trust and willingness to pay. To date, there is a dearth of literature investigating this relationship, yet willingness to pay is a powerful indication of consumers' value of the brand. In their model of brand love, Albert and Merunka (2013) suggested that brand trust positively influenced brand love, which influenced willingness to pay. Trust creates exchange relationships that are valued (Morgan and Hunt, 1994), and therefore it can be expected 
that trust will lead to a greater willingness to pay. For example, brand trust has been indirectly related to higher relative price (Chaudhuri and Holbrook, 2001). Therefore, we suggest a positive relationship between brand trust and willingness to pay a premium price. The study hypothesises:

H6: Brand trust is positively associated with willingness to pay a premium price.

\subsection{Online consumer brand identification}

As the study is interested in how brands on social media may form stronger friendships with consumers, we considered the concept of self-connection, from Fournier's (1998) concept of Brand Relationship Quality. Specifically, we investigate Online Consumer Brand Identification (OCBI). Consumer brand identification is defined as "the consumer's perceived state of oneness with a brand" (Stokburger-Suaer et al., 2012, p.407). In this study we consider consumer brand identification on social media, which is designated as OCBI. In line with the aforementioned definition of CBI, OCBI corresponds to the consumer's perceived state of oneness with a brand followed on social media. Our research focuses on consumers' identification with the brand on which the social network is cantered on (rather than identification with the social medium), as recent research indicates that brand identification is a stronger driver of brand outcomes, and identification with the social medium plays a lesser role (Popp and Wilson, 2018).

In an offline context, both Carroll and Ahuvia (2006) and Albert and Merunka (2013) found that overall brand identification had a strong influence on brand love. The consumer is likely to develop positive feelings towards a brand he/she identifies with (Harrison-Walker, 2001). Stokburger-Suaer et al., (2012) also agreed that affective responses such as brand love are emotional consequences of brand identification. We considered it interesting therefore to investigate whether this relationship was positive 
when the consumer was thinking about a brand they followed on their social media. It is hypothesised:

H7: Online consumer brand identification is positively associated with brand love.

The organizational behaviour literature is helpful in suggesting a positive relationship between $\mathrm{CBI}$ with brands followed on social media, and further outcomes. Specifically, when an individual identifies with an organization, they are likely to become advocates for that company (Ashforth and Mael, 1989), and engage in extra-role behaviours to support the organization (Ahearne et al., 2005). In the same way, Stokburger-Sauer et al., (2012) observed a significant positive relationship between CBI and brand advocacy. As noted earlier, extant literature has shown that advocacy is a component of co-creation of brand value (France et al., 2018). Therefore, the study investigates the influence of OCBI on intention to co-create brand value . It hypothesises: H8: Online consumer brand identification is positively associated with intention to co-create brand value.

Furthermore, the research posits a positive relationship between consumer brand identification and willingness to pay a premium price. The research seeks to better understand willingness to pay, as there is a dearth of knowledge between what consumers post about on social media and what they consume in the 'real' world (Schau and Gilly, 2003). Would consumers pay more for brands they identify with on social media? Extant literature on CBI is helpful, as it reveals that CBI results in brand loyalty (StokburgerSuaer et al., 2012), which could suggest that consumers with greater OCBI would be less price sensitive, as brand-loyal customers are usually willing to pay more for a brand (Chaudhuri and Holbrook, 2001). Moreover, Albert and Merunka (2013) found a strong 
relationship between consumer brand identification and brand love and between brand love and propensity to pay a higher price for the brand. Therefore, this study hypothesises:

\section{H9: Online consumer brand identification is positively associated with willingness to pay a premium price.}

\subsection{Brand love on social media}

As aforementioned, brand love is "the degree of passionate emotional attachment a satisfied consumer has for a particular trade name" (Carroll and Ahuvia, 2006, p.81). Extant literature suggests that brand love for brands on social media results in positive outcomes for the brand. For example, brand love as a consequence of Fan page liking has been identified as an antecedent of WOM and purchase intention (Kudeshia et al., 2016). By contrast, consumers who are annoyed with the brand's interactions on social media may turn against it, and stop co-creating value with it (Hutter et al., 2013). In further research on online brand engagement on social media, Loureiro et al. (2017) found that brand love mediated the relationship between online brand engagement and eWOM. They explained that "the emotional connection and the feeling of anxiety when not having the brand, make consumers more inclined to recommend the brand to others via online platforms" (Loureiro et al., 2017, p.1000). Moreover, Albert and Merunka (2013) found a positive relationship between brand love and word of mouth. The current study extends this idea beyond the concept of word of mouth to the broader concept of value co-creation, of which advocacy is a component (France et al., 2018). Kennedy and Guzmán (2020) found that consumers respond positively to brands that they consider positively, in

relation to both co-creation and brand love. We extend this idea by investigating a 
relationship between brand love and consumers' intention to co-create brand value with others on the social network. Therefore, the following hypothesis is investigated:

H10: Brand love positively influences intention to co-create brand value.

Furthermore, as noted earlier, brand love enhances consumers' willingness to pay a premium price for the brand (Albert and Merunka, 2013), in part because those who feel greatest love for the brand fear its loss and are willing to pay more to have access to it (Batra et al., 2012). Thompson et al. (2005) asserts that consumers' willingness to pay a premium price is affected by their level of attachment to the brand, as consumers who love brands will continue to buy them even when the price increases. Albert and Merunka (2013) also found that brand love increases willingness to pay.

Earlier it was noted that brands followed or Liked can be outside of the consumer's material reality (drawing on Schau and Gilly, 2003). Extant literature suggests that brand love for 'Liked' brands affects its purchase intention (Kudeshia et al., 2016), and in the online context, a recent study of Web dramas (Khan et al., 2021) found that individuals who are motivated to love a brand via social media are more likely to spend money on the loved brand. This study therefore asks: would consumers be willing to pay more for loved brands they follow on social media? Supported by the concept of brand equity (Yoo et al., 2000), it is asserted that consumers will consider that their online loved brands are also priceless, and they will be willing to pay a greater price to acquire them as a result. This study extends the extant theory to brands on social media, and hypothesises:

\section{H11: Brand love positively influences willingness to pay a premium price.}

In summary, the research model is presented in Figure 1.

(Insert Figure 1 about here) 


\section{Method}

\subsection{Participants}

The focus of the study is Generation $\mathrm{Y}$ and $\mathrm{Z}$ consumers in Portugal who follow brands on social media. While broader definitions of these age cohorts vary, a general consensus is that generation $\mathrm{Y}$ are those consumers aged between 18 and 37 years in 2018 (Nielsen, 2018a), and generation $\mathrm{Z}$ are those consumers aged between 14 and approximately 22 years (Patel, 2017). Some consider younger millennials as those aged 18-24 years, and older millennials as 25 to 37 years (Nielsen, 2018b). For clarity, and to avoid overlap in the study, Generation Y (Millennials) are defined as those aged from 24-38 years in 2021, and Generation $\mathrm{Z}$ as those aged up to 23 years in 2021 . These generations have a greater need to feel connected to the company that they do business with (Pasquarelli, 2018), and social media presents an opportunity to build relationships with this younger consumer. Therefore, they are an interesting age cohort for a study of brand love on social media.

In Portugal, the monthly active social network users was expected to reach 6.49 million individuals, or $63 \%$ of the population in 2019 (Statista, 2019). As noted earlier, these generations have a greater need to feel connected to the company that they do business with (Pasquarelli, 2018), and social media presents an opportunity to build relationships with the younger consumer. Therefore, they are interesting age cohorts for a study of brand love on social media.

Moreover, these younger consumers are notable as they have more confidence in technology and are high users of social media, and are therefore more likely to engage with the medium (Pasquarelli, 2018). Generations $\mathrm{Y}$ and $\mathrm{Z}$ have been described as 'digital natives' (Prensky, 2001), having come of age after the acceptance of digital 
technology. Therefore, they are uniquely positioned to provide insights into their relationships with brands on social media.

Furthermore, existing studies of social media use and brand relationships have focused on the younger consumer. For example, Machado et al.'s (2019) study exploring engagement and brand love on Facebook focused on consumers aged 29 years and under as it was in line with Facebook users' demographics'; in their study of brand value cocreation on a social network, Tajvidi et al. (2017) focused on users aged up to 30 years old; Bergkvist and Bech-Larsen (2010) study of brand love consequences and antecedents focused on a student sample. While the current study is not limited to students, it focuses on younger consumers as it asserts that Generations $\mathrm{Y}$ and $\mathrm{Z}$ consumers can contribute greater insights into the variables of interest.

\subsection{Measures}

The items used to assess the constructs were based on pre-existing scales from previous research, with minor adaptations. These scales have been tested and validated in extant studies and are presented in Table II. For all scales, a 7-point Likert-type scale was employed, ranging from 1 ("strongly disagree") to 7 ("strongly agree”).

In line with the broader brand engagement literature, online consumer brand engagement (OCBE) was measured as a second order construct that includes three dimensions: cognitive (OCBECog), affective (OCBEAff), and activation (OCBEAct). To measure these dimensions, the consumer brand engagement scale developed by Hollebeek et al. (2014) was used. These items describe consumer engagement when interacting with the brand on social media. Scale items include "When I am interacting with this brand I want to learn more about it" (OCBECog); "I feel very positive when I 
am interacting with this brand" (OCBEAff); and "I spend a lot of time interacting with this brand, compared to any other brand" (OCBEAct).

The measure of brand trust (BT) was the brand trust scale by Gurviez and Korchia (2002). This scale has been used in research on consumer-brand relationships, and in particular in investigating the relationship between trust and brand love (Albert and Merunka 2013). BT was measured as a second order construct that includes the following dimensions: credibility (BTCred), integrity (BTInte), and benevolence (BTBene), in line with Gurviez and Korchia (2002). Trust was measured with statements including "This brand's products make me feel safe" (BTCred); "This brand is sincere with its customers" (BTInte); and "I think this brand improves continuously its responses to customers' needs" (BTBene).

Online consumer brand identification (OCBI) was measured based on the Stokburger-Suaer et al., (2012) scale, applied in a social media context. Items included "I feel a strong sense of belonging to this brand".

Brand love (BL) was measured using an adaptation of the scale by Carroll and Ahuvia (2006). The scale included statements such as "This brand makes me very happy".

To measure the intention to co-create brand value (ICC) the scale that was developed by Tajvidi et al. (2017) was employed. This scale was particularly relevant for this study, as it was designed to capture intention to co-create value by brand pages users of an online site (Tajvidi et al., 2017). Measures relate to value co-creation about the brand with others on social media. Scale Items included "I am willing to provide my experiences and suggestions when my friends on my favourite social networking site want my advice on buying a brand". 
Finally, willingness to pay a premium price was assessed using the scale by Park and Kim (2014). Items included "I would be willing to pay a higher price at this store over other similar stores".

\subsection{Process}

An initial pilot study was conducted in Portugal, with 10 representative respondents, to confirm the comprehensibility of the scale items. Based on the results obtained in the pilot study, some modifications were made to the questions to improve the comprehensibility. The questionnaire used for the data collection advised the respondents to the rate the level of agreement and disagreement to each item considering their favourite brand. Answering the questionnaire for their most favourite brand on social media facilitated responses and this approach is in line with previous studies (e.g., Hegner et al., 2017; Fetscherin et al., 2014; Rauschnabel and Ahuvia, 2014).

The survey specifically targeted users of social networks, from Gen Y and Z, and was sent via a link provided on Facebook and Instagram. Participants were asked to answer the survey if they followed a brand on social media and to name that brand. The answers were collected from the $12^{\text {th }}$ February to the $21^{\text {st }}$ May 2018. From the 391 answers obtained, 332 were considered valid for the purpose of the study. Those cases omitted did not mention a brand, they had a high number of missing values, or they did not belong to the age demographic. The sample size is consistent with recent research on brand love and Fan pages (Kudeshia et al., 2016). All the participants followed at least one brand on social media. An overview of the brands followed by participants is presented in the Appendix. A full demographic profile of respondents is presented in Table I. 


\subsection{Non-response bias and common method bias}

Following the widely-used procedure recommended by Armstrong and Overton (1977) to test nonresponse bias (e.g., Alayo et al. 2019), the study compared the means obtained in two sub-samples (the total sample was split in half). The study used the $t$-test for equality of means. The results of the $t$-test show, with three exceptions, no significant differences, at the conventional significance level (5\%), between the means of the two groups of the 29 items used to measure the model constructs. The $1 \%$ significant level results indicated no differences between the two groups. Thus, non-response bias is not a major problem in this study.

Furthermore, as the sample was collected using self-reported data from the same respondents, using the same instrument, common method variance (CMV) was assessed. CMV arises when the variance of the responses is systematically attributable to the single measurement method used (Podsakoff et al., 2003; Podsakoff et al., 2012). In order to attend to this potential bias, ex ante and ex post procedures were employed. Ex ante, following the recommendations of Podsakoff et al. (2003), several control procedures were used.

These procedures included the following steps: the survey was pre-tested in order to define ambiguous terms and avoid vague concepts and complex syntax, avoid doublebarrelled questions, and keep each question simple, specific, and concise; in the first page of the questionnaire, respondents were assured that the answers are anonymous and advised that there were no right or wrong answers to each question. Ex post, the CMV can be tested using different techniques, such as Harman's single factor test, correlational marker technique, single unmeasured latent method factor, and multiple method factors 
(see Podsakoff et al., 2003, for a synthesis of these techniques). In this study, Harman's single-factor test was performed. This is the most frequently used approach according to Fuller et al. (2016). The exploratory factor analysis without rotation shows four factors with eigenvalues greater than 1.0 that accounted for $68.90 \%$ of the variance. The first factor accounts for $48.55 \%$ of the variance, which is below the $50 \%$ threshold suggested by Podsakoff and Organ (1986). Therefore, based on both ex ante and ex post procedures used, CMV is not a major issue in this study.

\subsection{Data analysis}

Structural equation modelling (SEM) was used to test the proposed model. SEM is a multivariate statistical analysis technique which 'combines the principles of factor analysis and multiple regression in one procedure' (Hair et al., 2006, p.724). SEM offers several advantages: it takes a confirmatory approach to data analysis, rather than an exploratory approach; explicit estimates of measurement error are presented, and it allows researchers to include unobserved (latent) and observed variables (Byrne, 2009).

\section{Results}

\subsection{Measurement model results}

The global proposed model comprises two components: the measurement component and the structural component. These components of the complete SEM can be estimated and evaluated conjunctly or separately. In this study, the two components of global model were estimated separately as recommended by Anderson and Gerbing (1988). These estimations were performed using the AMOS 25.0 software and the maximum likelihood (ML) estimation method. This method relies on the hypothesis of multi-normality distribution of the observed variables. However, the literature (e.g., Kline, 2017) 
advocates that this estimation method provides robust estimates for both parameters and standard errors when departure of multi-normality assumption is not severe. Following Kline (2017), the departure from normality assumption the skewness and kurtosis were assessed. The skewness ranges from -0.99 and 0.34 , and the kurtosis ranges from -1.17 and 0.38 . Thus, considering the thresholds (skewness $<3.0$ and kurtosis $<20.0$ ) proposed by Kline (2017), the departure from multi-normality distribution of the observed variables is not a major problem in the use of the ML estimation method.

A preliminary data analysis was then performed to detected items that were poorly correlated with the other items of the same scale. This analysis led to the elimination of some items of the original scales. Regarding OCBE, each of the three dimensions includes three items, only one item was dropped in OCBEAff which has four items in the original scale. The item dropped was "following this brand's FB account makes me happy".

The dimensions of BT include three items for BTCred, two items for BTInte (one item, "this brand expresses an interest in its customers" was dropped), and two items for BTBene. The OCBI scale has four items out of the five items of the original scale, and the item the item "this brand embodies what I believe in" was dropped. Items were dropped due to low communalities and cross-loadings. The scales for ICC and WPP are consistent with the extant literature. Regarding BL, following scale purification, four items were used in the present study. The purification was necessary to delete items and to ensure an acceptable measurement of the construct. Nevertheless, the retained items reflect the essence of brand love. Following the estimation and evaluation of measurement model of each construct (fits order and second order) was performed. To analyse global fit of each measurement model multi fit measure was used, namely, the chi-square $\left(\chi^{2}\right)$, goodness of fit index (GFI), incremental fit index (IFI), Tucker-Lewis index (TLI), comparative fit index (CFI), and root mean square error approximation (RMSEA). 
Previous research treated OCBE (e.g., Hollebeek et al., 2014) as second order construct of first order constructs: OCBECog, OCBEAff, and OCBEAct. BT was also treated as second order construct in past research (Gurviez and Korchia, 2002) including the following first order constructs: BTCred, BTInte, and BTBene. Hence, based on this theoretical support, in this study OCBE and BT were also considered second order constructs. In addition to extant theoretical support, this approach also has empirical support, taking into account the criteria pointed out by Koufteros et al. (2009) and Blome et al. (2014). These criteria are as follows: the loading factors of the second order and first order factors are all above 0.70 and they are statically significant (OCBE ranging from 0.791 to 0.954 ; BT ranging from 0.862 to 0.889 ); the ratio between the chi-square of the model that considers the construct as $1^{\text {st }}$ order and the model that treats the construct as $2^{\text {nd }}$ order is higher than 0.90 (ratio=1 in both cases); the obtained model guarantees convergent and discriminant validity; and, finally, the $2^{\text {nd }}$ order model has a good global fit regarding $\mathrm{OCBE}[\mathrm{GFI}=0.957, \mathrm{IFI}=0.981, \mathrm{TLI}=0.972, \mathrm{CFI}=0.982$, and $\mathrm{RMSEA}=$ $0.074]$ and $\mathrm{BT}[\mathrm{GFI}=0.980, \mathrm{IFI}=0.993, \mathrm{TLI}=0.987, \mathrm{CFI}=0.993$, and $\mathrm{RMSEA}=$ 0.063]. Therefore, considering OCBE and BT as $2^{\text {nd }}$ order constructs, and incorporating the remaining constructs outlined in the proposed model, the measurement model was estimated.

Table II shows the theoretical constructs $\left(1^{\text {st }}\right.$ and $2^{\text {nd }}$ order $)$, the final items used in the analysis, estimated results of the measurement model (standardized loadings, the $t$ statistics, and the $\mathrm{R}^{2}$ estimates), the Cronbach's alpha coefficients, the composite reliabilities (CR), and the average variance extracted (AVE). Although the chi-square is statistically significant $(\chi 2=839.67 ; d f=356, p<0.01)$, the model performed well to the data collected considering the other most popular goodness-of-fit statistics (IFI $=0.944$, $\mathrm{GFI}=0.845, \mathrm{TLI}=0.936, \mathrm{CFI}=0.944$, and RMSEA $=0.064)$. Regarding the particular 
aspects of the model fit, the standardized loadings are larger (all exceed the 0.50 threshold) and were all highly significant $(p<0.01)$, and $\mathrm{R}^{2}$ estimates were all above the 0.20 threshold. These results provided support for convergent validity of the variables.

\section{(Insert Table II about here)}

The additional proprieties of the measurement analysis, such as Cronbach's alpha values, CR, and AVE estimates are also presented in Table II. The Cronbach's alpha values ranges from 0.813 to 0.968 and the $C R$ varies between 0.813 and 0.968 , both exceeded the 0.70 threshold. These results provide support that the scales are internally consistent (Fornell and Larcker, 1981). The AVE estimates for all constructs are larger than the 0.50 benchmark and are greater than the square correlations among the corresponding constructs (see Table III). Thus, discriminant validity is also supported (Fornell and Larcker 1981).

\section{(Insert Table III about here)}

\subsection{Structural model results}

After fixing the measurement model, the structural model was estimated and evaluated to test the hypotheses outlined in the conceptual model. Table IV shows the standardized structural coefficient estimates, the $t$-statistics, and the summary of the hypotheses tests.

\section{(Insert Table IV about here)}

The different goodness-of-fit statistics used shows provided supported for the structural model. Although the chi-square is statistically significant $(\chi 2=842.78 ; d f=$ $357, p<0.01)$, the remaining overall model fist statistics suggest an acceptable model fit to data collected in the sample $(\mathrm{IFI}=0.944, \mathrm{GFI}=0.844, \mathrm{TLI}=0.936, \mathrm{CFI}=0.944$, and 
RMSEA $=0.064)$. All the paths estimated have the anticipated sign and the majority $(8$ out of 11) are statistically significant at the conventional significant level. An inspection to the modification indices reveals that no other path is statistically significant at the conventional significant level; this result supports the proposed model. A summary of the structural results is presented in Figure 2.

(Insert Figure 2 about here)

\section{Discussion}

Strong brand relationships are governed by the strength of feeling towards the brand, and a willingness to connect with the brand (Veloutsou, 2009). Given the contributions of strong brand relationships to financial performance (Dessart et al., 2015), and the ubiquity and relatively low cost of social media for brand managers, it is perhaps surprising that few studies have investigated the impact of antecedents and outcomes of strong brand feeling, specifically brand love, in the online context (Machado et al., 2019). This study shows that brand love is an important antecedent of positive brand outcomes, for followers of brands on social media. Focusing on Generation $\mathrm{Y}$ and Z, because of their level of interaction with social media (Statista, 2020), we show that these young consumers will co-create value (ICC) for the brand they follow online, and pay a premium price (WPP) for that brand, if they love the brand.

Furthermore, we show that brand trust is essential for this cohort, as brand trust is positively associated with brand love, intention to co-create value, and willingness to pay a premium. Therefore, although younger consumers may be maligned for following brands on social media without any offline intent (Wallace et al., 2014), we show that this is not always the case. We suggest that consumers seek 'authentic' relationships with their brands, and when this is achieved through brand trust and brand love, brand 
outcomes (ICC and WPP) are enhanced. We also show that online consumer brand identification will only result in co-creation of value or willingness to pay a premium price if the consumer experiences brand love. These findings have a number of important implications for theory and practice.

\subsection{Theoretical Implications}

Within the consumer brand relationship literature, it is recognised that consumers who have strong emotions will actively interact with the brand (Veloutsou, 2009). On social media, existing research has highlighted the importance of investigating the relationship between brand love and brand outcomes (Machado et al., 2019). Our study investigates constructs related to consumer brand relationships across social media platforms. Moreover, extant research does not measure the breadth of constructs investigated in our study. For example, Machado et al.'s (2019) study substantially advances literature regarding engagement, brand love, and $\mathrm{CBBE}$, but the brand love outcomes willingness to pay and intention to co-create value were outside of the scope of their study. Mollen and Wilson (2010) proposed ideas related to brand engagement and co-creation of value, but they did not test this empirically; Kennedy and Guzmán (2020) highlighted the importance of brand trust for value co-creation, but they did not measure trust in their study.

We believe that we are the first study to consider both brand trust and online brand engagement as antecedents of brand love, and to investigate the role of brand love for outcomes intention to co-create value (ICC) and willingness to pay a premium (WPP). Moreover, our study extends understanding of consumer brand identification (CBI) by investigating online consumer brand identification (OCBI) as a new construct, and 
identifying the mediating role of brand love in the relationship between OCBI and both ICC and WPP.

Our findings show that online brand engagement is significant in predicting consumers' intention to co-create brand value. This finding is consistent with extant literature that suggests engagement fosters a two-way interaction (Brodie et al., 2011), and enhances brand co-creation behaviour (France et al., 2018), however, it extends this finding to social media. The study shows that a 'virtuous cycle' can be generated, whereby consumers who are engaged with the brand's social media will engage in value co-creation. It is recommended that social media managers would ensure that their brands are responsive to consumer interactions. Consumers' perceptions of brand responsiveness to their interactions has been posited to motivate co-creation (Mollen and Wilson, 2010). The current study empirically supports this contention, as it shows that consumers will co-create further value if they feel cognitive, affective, and active online engagement towards the brand online.

Second, findings show that online brand engagement with brands is not directly significant in predicting willingness to pay a premium price (WPP) for those brands, unless the brand is loved. This is an important finding as recent research on brand engagement and brand outcomes had not considered WPP as an outcome (for example, Machado et al., 2019). We suggest that consumers who are engaged with brands online may be engaged with other members of the social network, and therefore may be motivated to seek to content to engage with those others on the network, rather than with the brand. Findings show that consumers who appear engaged with brands on social media may not always be willing to pay a premium price for those brands. This finding advances the assertion by Schau and Gilly (2003) that those who post about brands on social media may not consume these brands in their material realities. The findings 
suggest that managers seeking to enhance WPP among consumers who engage online, should seek to foster brand love among those consumers. For example, extant research suggests that self-expressive brands will foster brand love (Carroll and Ahuvia, 2006). As social media platforms such as Facebook and Instagram are highly self-expressive mechanisms, brands could enhance messages that allow the consumer to represent themselves through their brand choices on these media, thereby enhancing brand love and, ultimately, WPP.

Third, findings extend the existing literature that suggests brand trust determines brand love, to brand trust and love on social media. Kennedy and Guzmán (2020) had asserted that trust is paramount to brand relationship, but their study had not specifically measured brand trust. We show that their assertion is true, and we show this in the context of social media. However, it is important to note that the extension of extant literature to social media is greater than context, as brands on social media do not require material ownership, and have a self-expressive function (Hollenbeck and Kaikati, 2012; Schau and Gilly, 2003). Albert and Merunka (2013, p. 262) noted that "when a consumer believes he or she can rely on the brand, it facilitates the development of a love feeling". Findings support this assertion in relation to brand trust and brand love.

Fourth, extant literature emphasizes trust as a central component of relationship quality (Morgan and Hunt 1994), and critical when forming relationships on social media (Gleeson 2012). The current study also shows that, for brands followed on social media, online trust influences brand love, intention to co-create brand value (ICC), and willingness to pay a premium price for the brand (WPP). Findings in relation to ICC support existing research that suggests consumers will open up to brands when they trust them (Schoenbachler and Gordon, 2002), and findings also indicate that consumers who trust a brand will co-create value with others in relation to that brand. In this way, we 
advance the research of Tajvidi et al. (2017) who also hypothesised that brand trust would be positively associated with ICC, but their measure of brand trust was incorporated in a broader measure of relationship quality. By measuring brand trust as a separate construct, we provide further support for their assertion.

Fifth, findings show that brand trust enhances WPP. Trust relationships are more valued (Morgan and Hunt, 1994). The current study extends the application of this long held theory, as it shows that brand trust relationships with brands on social media also enhance value offline, evidenced by consumers' WPP. This is a notable finding, as it has been suggested by the literature that online interactions with brands may be solely for self-enhancement purposes (for example Hollenbeck and Kaikati, 2012), but this study shows that if the brand is trusted online it enhances offline consumer behaviours also, evidenced through greater WPP.

Sixth, findings support extant consumer brand relationship literature, as they indicate a positive relationship between brand trust and brand love (Albert and Merunka, 2013). Results show that although brand trust enhanced ICC and WPP, this effect is enhanced when the brand is also loved.

Seventh, findings show a positive relationship between online consumer brand identification (OCBI) and brand love. This finding supports existing research (Albert and Merunka, 2013, p.263) which found that brand identification positively influenced brand love, as "the customer must feel psychological proximity to develop an affective proximity with the brand". The study offers a contribution by extending the concept of consumer brand identification to the online context, showing that this 'psychological proximity' extends to social media as online consumer brand identification, as findings indicate that consumers who identify with the brand online also have greater brand love. 
Eighth, findings indicate that OCBI positively influences intention to co-create value and willingness to pay a premium price only when moderated by brand love. This draws on the concept of targets of identification by Popp and Wilson (2018). They argued that the target of identification may be the social media itself, other consumers on social media, or the brand, and these targets have differential effects on outcomes, with consumer brand identification driving brand loyalty and WOM. The study advances this idea as it indicates that brand love is required to foster WPP when there is consumer brand identification with brands on social media.

\subsection{Managerial Implications}

Findings suggest that managers would be aware that online brand relationships may be somewhat superficial, driven solely by self-enhancement motives and a desire to engage with others online rather than the brand itself, unless trust and love for the brand are present. We show that although ICC can be enhanced by OCBE and OCBI, these antecedents are not significant in predicting WPP unless mediated by brand love. Findings indicate that brand trust will enhance WPP, both as an antecedent of brand love and when this relationship is mediated by brand love. Therefore, firms should seek to build friendships with Generation $\mathrm{Y}$ and $\mathrm{Z}$ consumers through enhancing trust and love, as the study shows that that trust and love are both critical in enhancing both ICC and WPP for brands on social media.

Given the importance of value co-creation and willingness to pay a premium price to the firm, how can managers enhance brand trust and brand love through social media? This study suggests that managers would seek to enhance the authenticity of their brands on social media, as authenticity enhances the self-congruity of the brand (Morhart et al., 2015). Authenticity emerges "to the extent to which consumers perceive a brand to be 
faithful and true toward itself and its consumers, and to support consumers being true to themselves" (Morhart et al., 2015, p.202) where the brand has consistency, honesty, and genuineness (Fritz et al., 2017). Authenticity is enhanced by dimensions including credibility (such as encouraging brand-congruent employee behavior) (Morhart et al., 2015), and an appeal to actual self-congruence (Fritz et al., 2017).

As credibility shares conceptual components with trust, such as delivering on what is promised, and acting with honesty (Morhart et al., 2015), it is suggested that enhancing messages of credibility on social media will also enhance trust. Moreover, managers should ensure that their brand communicates its integrity (such as adopting a communication style emphasizing the brand's virtue), which will enhance the affective response to the brand (Morhart et al., 2015), such as brand love (Carroll and Ahuvia, 2006).

Brands that set their ideals too far out of reach may be perceived as inauthentic, leading to customer detachment. Brands are advised to present their 'real' selves on social media. The findings suggest that brands utilizing social media to build relationships with younger consumers could communicate these dimensions of their brands, to enhance brand relationships (Fritz et al., 2017) via brand trust and brand love, resulting in positive outcomes such as WPP and ICC.

\subsection{Limitations and future research}

As with all research there are limitations to this study. The study is limited to Generation $\mathrm{Y}$ and $\mathrm{Z}$ consumers. Older consumers may be less likely to use social media, or to engage to the same extent online, for example through value co-creation. Further research is recommended to investigate the model with older consumers, for example Generation X or Baby Boomers. However, given the importance of social media to Generation Y and 
$\mathrm{Z}$, the insights provided are valuable in understanding the role of brand love in building friendships with these age cohorts.

The study invited participants to name the brand they followed on social media and to answer the survey considering that brand (please see the Appendix for a summary of these brands). Many of the brands are in the hedonic (for example entertainment) or self-expressive/conspicuous (for example fashion clothing) categories. These brands may be more loved, as they are self-expressive (Carroll and Ahuvia, 2006). Further research might conduct similar research among business-to-business customers who interact with brands on social media, or consumers who interact with utilitarian brands on social media, to test the role of brand love in fostering relationships in those contexts.

\section{Conclusion}

While social media remain popular with younger generations, the relationship between online behaviour and offline brand intentions is less well understood. Little is known about the factors that influence consumers' intention to co-create value (ICC) on social media, or their willingness to pay a premium price (WPP) for the brands they interact with online. This study provides important insights into the role of brand love in enhancing both ICC and WPP, for brands followed on social media. The study also highlights the importance of brand trust in influencing brand love and brand outcomes. Marketers may be well advised to take advantage of the opportunities presented by social media for fostering stronger brand relationships with these younger consumers. 


\section{References}

Ahearne, M., Bhattacharya, C.B., and Gruen, T. (2005), “Antecedents and consequences of customer- company identification: Expanding the role of relationship marketing", Journal of Applied Psychology, Vol. 90 No. 3, pp. 574-585.

Alayo, M., Maseda, A., Iturralde, T., and Arzubiaga, U. (2019), "Internationalization and entrepreneurial orientation of family SMEs: The influence of the family character", International Business Review, Vol. 28 No. 1, pp. 48-59.

Albert, N., Merunka, D. and Valette-Florence, P., (2013), "Brand passion: Antecedents and consequences", Journal of Business Research, Vol. 66 No. 7, pp.904-909.

Albert, N. and Merunka, D. (2013), "The role of brand love in consumer-brand relationships", Journal of Consumer Marketing, Vol. 30 No. 3, 258-266.

Albert, N., Merunka, E., and Valette-Florence, P. (2008), "When consumers love their brands: exploring the concept and its dimensions", Journal of Business Research, Vol. 61 No. 10, pp. 1062-1075.

Algharabat, R.S. (2017), "Linking social media marketing activities with brand love: The mediating role of self-expressive brands”, Kybernetes, Vol. 46 No. 10, pp. 18011819.

Anderson, J.C. and Gerbing, D.W. (1988), "Structural equation modelling in practice: A review and recommended two-step approach”, Psychology Bulletin, Vol. 103 No. 3, pp. 411-413.

Armstrong, J.S. and Overton, T.S. (1977), "Estimating nonresponse bias in mail surveys", Journal of Marketing Research, Vol. 14 No. 4, pp. 396-402.

Ashforth, B.E. and Mael, B. (1989), "Social identity theory and organization", The Academy of Management Review, Vol. 14 No. 1, pp. 20-39. 
Bagozzi, R.P., Batra, R., and Ahuvia, A.C. (2017), "Brand love: Development and validation of a practical scale”, Marketing Letters, Vol. 28 No. 1, pp. 1-14.

Batra, R., Ahuvia, A., and Bagozzi, R. (2012), "Brand love”, Journal of Marketing, Vol. 76 No. 2, pp. 1-16.

Bergkvist, L. and Bech-Larsen, T. (2010), “Two studies of consequences and actionable antecedents of brand love", Journal of Brand Management, Vol. 17 No. 7, pp. $504-518$.

Blome, C., Schoenherr, T., and Eckstein, D. (2014), “The impact of knowledge transfer and complexity on supply chain flexibility: A knowledge-based view", International Journal of Production Economics, Vol. 147 Part B, pp. 307-316.

Brodie, J. R., Hollebeek., L., Jurić, L., and Ilić, A. (2011), “Consumer engagement: conceptual domain, fundamental propositions and implications for research”, Journal of Service Research, Vol. 66 No. 1, pp. 105-114.

Byrne, B. (2009), Structural Equation Modeling with AMOS: Basic concepts, Applications, and Programming (2nd Edition), New York: Taylor \& Francis.

Carroll, B.A. and Ahuvia, A.C. (2006), "Some antecedents and outcomes of brand love", Marketing Letters, Vol. 17 No. 2, pp. 79-89.

Chaudhuri, A. and Holbrook, M.B. (2001), "The chain of effects from brand trust and brand affect to brand performance: The role of brand loyalty", Journal of Marketing, Vol. 65 No. 2, pp. 81-93.

Coelho, A., Bairrada, C. and Peres, F., (2019), "Brand communities' relational outcomes, through brand love", Journal of Product \& Brand Management. Vol. 28 No. 2, pp. 154-165. 
Dessart, L., Veloutsou, C., and Morgan-Thomas, A. (2015), "Consumer engagement in online brand communities: a social media perspective", Journal of Product and Brand Management, Vol. 24 No. 1, pp. 28-42.

Felix, R., Rauschnabel, P.A., and Hinsch, C. (2017), "Elements of strategic social media marketing: A holistic framework", Journal of Business Research, Vol. 70, pp. 118-126.

Fetscherin, M., Boulanger, M., Filho, C.G., and Souki, G.Q. (2014), “The effect of product category on consumer brand relationships", Journal of Product and Brand Management, Vol. 23 No. 2, pp. 78-89.

Fetscherin, M., Guzmán, F., Veloutsou, C., and Cayolla, R.C., (2019), "Latest research on brand relationships: introduction to the special issue", Journal of Product and Brand Management, Vol. 28, No. 2, pp. 133-139.

Fornell, C. and Larcker, D.F. (1981), "Evaluating structural equation models with unobservable variables and measurement error", Journal of Marketing Research, Vol. 18 No. 1, pp. 39-50.

Fournier, S. (1998), “Consumers and Their Brands: Developing relationship theory in consumer research", Journal of Consumer Research, Vol. 24 No. 4, pp. 343-373.

Fournier, S. and Avery, J. (2011), "The uninvited brand”, Business Horizons, Vol. 54 No. 3, pp. 193-207.

France, C., Grace, D., Merrilees, B., and Miller, D. (2018), “Customer brand co-creation behavior: conceptualization and empirical validation”, Marketing Intelligence \& Planning, Vol. 36 No. 3, pp. 334-348.

Fritz, K., Schoenmueller, V., and Bruhn, M. (2017), "Authenticity in branding exploring antecedents and consequences of brand authenticity", European Journal of Marketing, Vol. 51 No. 2, pp. 324-348. 
Fuller, C.M., Simmering, M.J., Atinc, G., Atinc, Y., and Babin, B.J. (2016), “Common methods variance detection in business research", Journal of Business Research, Vol. 69 No. 8, pp. 3192-3198.

Gleeson, B. (2012), “6 ways brands build trust through social media”. Available at https://www.forbes.com/sites/brentgleeson/2012/10/31/6-ways-brands-buildtrust-through-social-media/\#25a2afff867d (accessed 12 March 2021).

Gómez, M., Lopez, C. and Molina, A., (2019), “An integrated model of social media brand engagement", Computers in Human Behavior, Vol. 96, pp. 196-206.

Gretry, A., Horváth, C., Belei, N., and van Riel, A.C.R. (2017), "Don’t pretend to be my friend! When an informal brand communication style backfires on social media", Journal of Business Research, Vol. 74, pp. 77-89.

Gurviez, P. and Korchia, M. (2002), «Proposition d'une échelle de mesure multidimensionnelle de la confiance dans la marque», Recherché et Applications en Marketing (French Edition), Vol. 17, pp. 41-61.

Hair, J.F.Jr., Black, W.C., Babin, B.J., Anderson, R.E., and Tatham, R.L. (2006), Multivariate Data Analysis (6 ${ }^{\text {th }}$ Edition), Pearson Prentice Hall: Upper Saddle River, NJ.

Hajli, M.N. (2014), “A study of the impact of social media on consumers”. International Journal of Market Research, Vol. 56 No. 3, pp. 387-404.

Harrison-Walker, L.J. (2001), “The measurement of word-of mouth communication and an investigation of service quality and customer commitment as potential antecedents", Journal of Service Research, Vol. 4 No. 1, pp. 60-75.

Hayes, R.A., Carr, C.T., and Wohn, D.Y. (2016), “One click, many meanings: interpreting paralinguistic digital affordances in social media”. Journal of Broadcasting \& Electronic Media, Vol. 60, pp. 171-187. 
Hegner, S.M., Fenko, A., and Teravest, A. (2017), "Using the theory of planned behaviour to understand brand love", Journal of Product \& Brand Management, Vol. 26 No. 1, pp. 26-41.

Hoffman, D. and Fodor, M. (2010), "Can you measure the ROI of your social media marketing?” MIT Sloan Management Review, Vol. 52, No. 1, pp. 41-49.

Hollebeek, L.D. (2011), "Demystifying customer brand engagement: exploring the loyalty nexus", Journal of Marketing Management, Vol. 27 No. 7-8, pp. 785-807.

Hollebeek, L.D., Glynn, M.S., and Brodie, R. J. (2014), “Consumer brand engagement in social media: Conceptualization, scale development and validation", Journal of Interactive Marketing, Vol. 28 No. 2, pp. 149-165.

Hollenbeck, C.R. and Kaikati, A.M. (2012), “Consumers' use of brands to reflect their actual and ideal selves on Facebook", International Journal of Research in Marketing, Vol. 29 No. 4, pp. 395-405.

Hootsuite.com (2019), "How to run a Successful Facebook contest: Ideas, tips and examples (online). Available at: https://blog.hootsuite.com/facebook-contestrules-tips-ideas/ (accessed 12 March 2021).

Hudson, S., Huang, L., Roth, M.S. and Madden, T.J. (2016), “The influence of social media interactions on consumer-brand relationships: A three-country study of brand perceptions and marketing behaviors", International Journal of Research in Marketing, Vol. 33 No. 1, pp.27-41.

Hutter, K., Hautz, J., Dennhardt, S. and Füller, J., (2013), „,The impact of user interactions in social media on brand awareness and purchase intention: the case of MINI on Facebook", Journal of Product \& Brand Management, Vol. 22, No. 5/6, pp. 342351. 
Junaid, M., Hou, F., Hussain, K. and Kirmani, A.A., (2019), "Brand love: the emotional bridge between experience and engagement, generation-M perspective”, Journal of Product \& Brand Management, Vol. 28 No.2, pp. 200-215.

Kaufmann, H.R., Loureiro, S.M.C, and Manatioti, A. (2016), "Exploring behavioural branding, brand love and brand co-creation", Journal of Product \& Brand Management, Vol. 25 No. 6, pp. 516-526.

Kennedy, E. and Guzmán, F. (2016), “Co-creation of brand identities: consumer and industry influence and motivations", Journal of Consumer Marketing, Vol. 33 No. 5, pp. 313-323.

Kennedy, E. and Guzmán, F., (2020), "No matter what you do, I still love you: an examination of consumer reaction to brand transgressions". Journal of Product \& Brand Management Vol. ahead-of-print No. ahead-ofprint. https://doi.org/10.1108/JPBM-07-2019-2450

Khan, J., Pelet, J.E. and Zamani, S. (2021). Tickle me on WeChat Moments: the role of brand love. Journal of Product \& Brand Management Vol. ahead-of-print No. ahead-of-print. https://www.emerald.com/insight/content/doi/10.1108/JPBM-10$\underline{2019-2597 / f u l l / h t m l}$

Kim, C.K., Han, D., and Park, S.-B. (2001), "The effect of brand personality and brand identification on brand loyalty: Applying the theory of social identification", Japanese Psychological Research, Vol. 43 No. 4, pp. 195-206.

Kline, R. (2017), Principles and practice of structural equation modeling ( $\left.3^{\text {rd }} \mathrm{ed}.\right)$. New York: The Guildford Press.

Koufteros, X., Babbar, S., and Kaighobadi, M. (2009), “A paradigm for examining second-order factor models employing structural equation modelling", International Journal of Production Economics, Vol. 120 No. 2, pp. 633-652. 
Kozinets, R., de Valck, K., Wojnicki, A.C., and Wilner, S.J.S. (2010), "Networked narratives; understanding word-of-mouth marketing in online communities", Journal of Marketing, Vol. 74 No. 2, pp. 71-89.

Kudeshia, C., Sikdar, P., and Mittal, A. (2016). "Spreading love through fan page liking: A perspective on small scale entrepreneurs", Computers in Human Behavior, Vol. 54 , pp. $257-270$.

Langner, T., Schmidt, J., and Fischer, A. (2015), "Is it really love? A comparative investigation of the emotional nature of brand and interpersonal love", Psychology \& Marketing, Vol. 32 No. 6, pp. 624-634.

Laroche, M., Habibi, M.R., Richard, M.O., and Sankaranarayanan, R. (2012), "The effects of social media based brand communities on brand community markers, value creation practices, brand trust and brand loyalty", Computers in Human Behavior, Vol. 28 No. 5, pp. 1755-1767.

Lipsman, A., Mudd, G., Rich, M., \& Bruich, S. (2012), “The power of like: How brands reach (and influence) fans through social media marketing”, Journal of Advertising, Vol. 42, No. 1, pp. 40-52.

Loureiro, C.M.C., Gorgus, T., and Kaufmann, H.R. (2017), “Antecedents and outcomes of online brand engagement: The role of brand love on enhancing electronicword-of-mouth", Online Information Review, Vol. 47 No. 7, pp. 986-1005.

Machado, J.C., Vacas-de-Carvalho, L., Azar, S.L., Andre, A.R., and dos Santos, B.P. (2019), "Brand gender and consumer-based brand equity on Facebook: The mediating role of consumer-based brand engagement and brand love', Journal of Business Research, Vol. 96, pp. 736-385. 
Mollen, A. and Wilson, H. (2010), "Engagement, telepresence and interactivity in online consumer experience: Reconciling scholastic and managerial perspectives", Journal of Business Research, Vol. 63 No. 9-10, pp. 919-925.

Morgan. R.M. and Hunt, S.D. (1994), “The commitment-trust theory of relationship marketing", Journal of Marketing, Vol. 58 No. 3, pp. 20-38.

Morhart, F., Malär, L., Guèvremont, A., Girardin, F., and Grohmann, B. (2015), "Brand authenticity: an integrative framework and measurement scale", Journal of Consumer Psychology, Vol. 25 No. 2, pp. 200-218.

Muniz, A.M. and O'Guinn, T.C., (2001), "Brand community”, Journal of Consumer Research, Vol. 27 No. 4, pp.412-432.

Nielsen (2018a), "Millennials on millennials: in the know, on the go!", available at https://www.nielsen.com/us/en/insights/article/2018/millennials-on-millennialsin-the-know-on-the-go/ (accessed 12 March 2021).

Nielsen (2018b), "Gen Z: The Elusive Generation", available at https://www.nielsen.com/eu/en/insights/news/2018/gen-z-the-elusivegeneration.html (accessed $21^{\text {st }}$ September 2020).

Palusuk, N, Koles, B. and Hasan, R. (2019), “All you need is brand love: a critical review and comprehensive conceptual framework for brand love", Journal of Marketing Management, Vol. 35, No. 1-2, pp. 97-129.

Pandora (2018) Annual Report, available at https://pandoragroup.com/investor/newsand-reports/annual-reports (accessed 12 $2^{\text {th }}$ March 2021).

Park, C. W., MacInnis, D. J., \& Eisingerich, A. B. (2016), Brand admiration: Building a business people love. New Jersey: John Wiley \& Sons. 
Park, H. and Kim, Y. (2014), "The role of social network websites in the consumer-brand relationship", Journal of Retailing and Consumer Services, Vol. 21 No. 4, pp. 460-467.

Pasquarelli, A. (2018), "Banking on youth: economic crisis during childhood has left a mark”. Advertising Age, January $22^{\text {nd }}$ (online). Available at: https://adage.com/article/news/banking-youth/312006/ (accessed 12 $12^{\text {th }}$ March 2021).

Patel, D. (2017). "8 ways Generation Z will differ from Millennials in the workplace" Forbes (online). Available at: https://www.forbes.com/sites/deeppatel/2017/09/21/8-ways-generation-z-willdiffer-from-millennials-in-the-workplace/\#38ba7ee376e5 (accessed $12^{\text {th }}$ March 2021).

Podsakoff, P.M, MacKenzie, S.B., Lee, J.-Y., and Podsakoff, N.P. (2003), “Common method biases in behavioral research: A critical review of the literature and recommended remedies", Journal of Applied Psychology, Vol. 88 No. 5, pp. 879903.

Podsakoff, P.M. and Organ, D.W. (1986), "Self-reports in organizational research: Problems and prospects", Journal of Management, Vol. 12 No. 4, pp. 531-544.

Podsakoff, P.M., MacKenzie, S.B., and Podsakoff, N.P. (2012), "Sources of method bias in social science research and recommendations on how to control it", Annual Review of Psychology, Vol. 63, pp. 539-569.

Popp, B. and Wilson, B., 2018. Investigating the role of identification for social networking Facebook brand pages. Computers in Human Behavior, 84, 141-152. Prensky, M. (2001), "Digital Natives, Digital Immigrants Part 1", On the Horizon, Vol. 9 No. 5, pp. 1-6. 
Rauschnabel, P. and Ahuvia, A. (2014), "You're so lovable: anthropomorphism and brand love", Journal of Brand Management, Vol. 21 No. 5, pp. 372-395.

Roberts, D., Hughes, M. and Kertbo, K. (2014), “Exploring consumers' motivations to engage in innovation through co-creation activities", European Journal of Marketing, Vol. 48, No.s 1/2, pp. 147-169.

Russell, J.A. and Barrett, L.F. (1999), “Core affect, prototypical emotional episodes, and other things called emotion: dissecting the elephant", Journal of Personality and Social Psychology, Vol. 76 No. 5, pp. 805-819.

Schau, H. J. and Gilly, M.C (2003), "We are what we post? Self-presentation in personal web space," Journal of Consumer Research, Vol. 30 No. 3, pp. 385-404.

Schmid, D.A. and Huber, F. (2019), "Brand love: Emotionality and development of its elements across the relationship lifecycle”, Psychology \& Marketing, Vol. 36 No. $4,305-320$.

Shoenbachler, D.D. and Gordon, G.L. (2002), "Trust and customer willingness to provide information in database-driven relationship marketing", Journal of Interactive Marketing, Vol. 16, pp. 2-16.

Smith, A.M. (2013), "The value co-destruction process: a customer resource perspective", European Journal of Marketing, Vol. 47 No.s 11/12, pp. 1889-1909.

Statista (2019), "Forecast of social network user numbers in Portugal from 2015 to 2022 (in million users)”. Available at: https://www.statista.com/statistics/569032/predicted-number-of-social-networkusers-in-portugal (accessed $21^{\text {st }}$ April 2020).

Statista (2021), "Distribution of Instagram users worldwide as of January 2021, by age group". Available at https://www.statista.com/statistics/325587/instagramglobal-age-group/ (accessed 12 ${ }^{\text {th }}$ March 2021). 
Stephen, A.T. (2016), "The role of digital and social media marketing in consumer behavior", Current Opinion in Psychology, Vol. 10, pp. 17-21.

Stokburger-Suaer, N., Ratneshwar, S., and Sen, S. (2012), "Drivers of consumer-brand identification", International Journal of Research in Marketing, Vol. 29 No. 4, pp. 406-418.

Tajvidi, M., Wang, Y., Hajli, N., and Love, E.D. (2017), "Brand value Co-creation in social commerce: The role of interactivity, social support, and relationship quality", Computers in Human Behavior, Vol. 115 p. 105238.

Thompson, M., MacInnis, D.J., and Park, C.W. (2005), “The Ties That Bind: Measuring the Strength of Consumers' Emotional Attachments to Brands", Journal of Consumer Psychology, Vol. 15 No. 1, pp. 77-91.

Vargo, S.L. and Lusch, R.F. (2004), "Evolving to a new dominant logic for marketing", Journal of Marketing, Vol. 68 No. 1, pp. 1-17.

Veloutsou, C. (2009), "Brands as relationship facilitators in consumer markets", Marketing Theory, Vol. 9 No. 1, pp. 127-130.

Veloutsou, C. and Moutinho, L. (2009), "Brand relationships through brand reputation and brand tribalism", Journal of Business Research, Vol. 62 No. 3, pp. 314-322.

Vernuccio, M., Pagani, M., Barbarossa, C., and Pastore. A. (2015), “Antecedents of brand love in online network-based communities. A social identity perspective", Journal of Product \& Brand Management, Vol. 24 No. 7, pp. 706-719.

Wallace, E., Buil, I. and de Chernatony, L., (2017), “Consumers' self-congruence with a "Liked" brand: Cognitive network influences and brand outcomes". European Journal of Marketing, Vol. 51, No. 2, pp. 367-390. 
Wallace, E., Buil, I. and de Chernatony, L., (2014). Consumer engagement with selfexpressive brands: brand love and WOM outcomes. Journal of Product \& Brand Management, Vol. 23, No. 1, pp. 33-42.

Yoo, B. , Donthu , N., and Lee, S.( 2000 ), “An Examination of Selected Marketing Mix Elements and Brand Equity", Journal of the Academy of Marketing Science, Vol. 28 No. 2, pp. $195-211$. 
Figure 1: Conceptual model

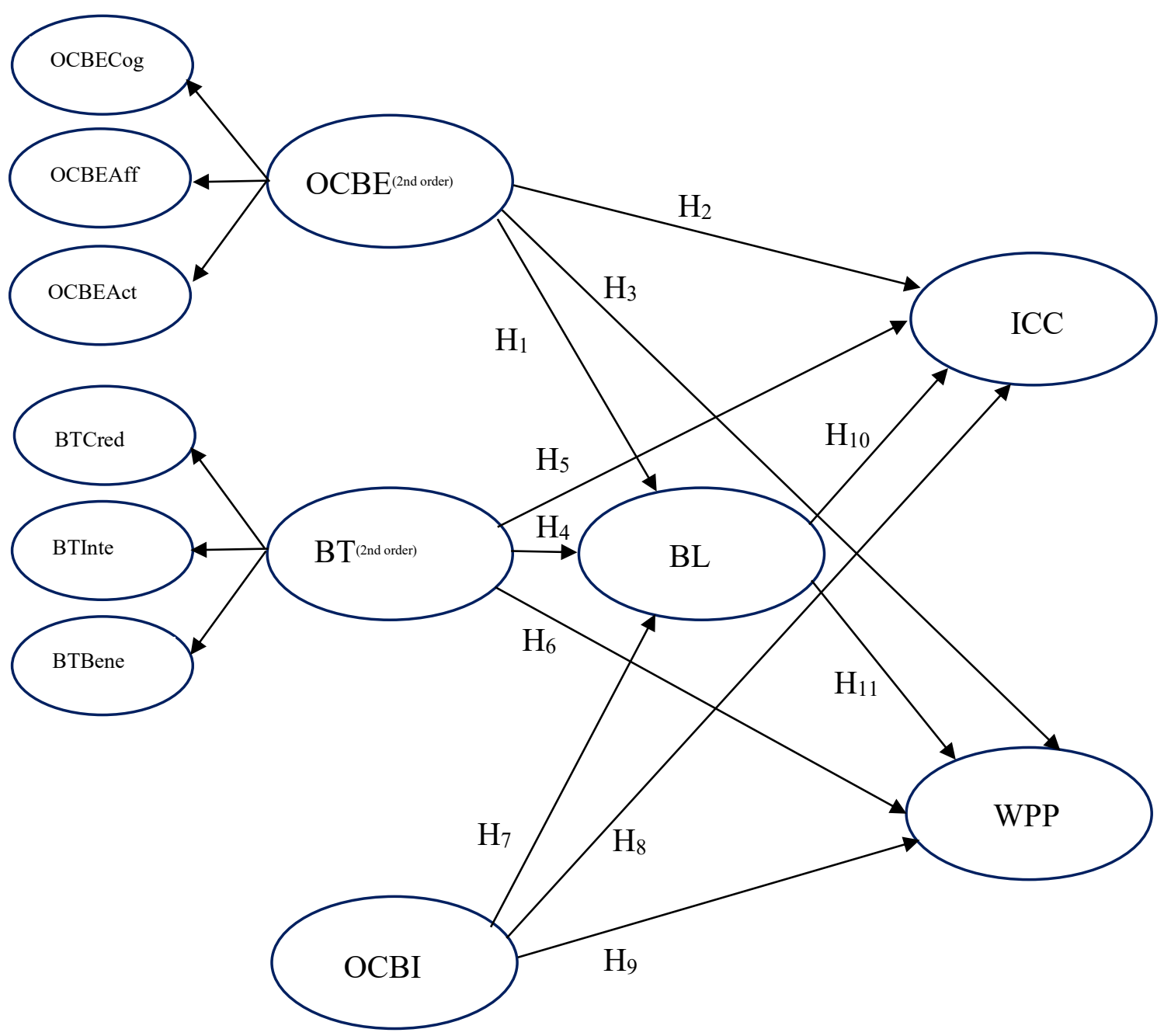

\section{Legend:}

$\mathrm{OCBE}=$ Online consumer brand engagement $\mathrm{OCBE}_{\mathrm{Cog}}=$ Online consumer brand engagement cognitive; $\mathrm{OCBE}_{\text {Aff }}=$ Online consumer brand engagement affective; $\mathrm{OCBE}_{\mathrm{Act}}=$ Online consumer brand engagement active; $\mathrm{BT}=$ Brand trust; $\mathrm{BT}_{\text {Cred }}=$ Brand trust credibility; $\mathrm{BT}_{\text {Inte }}=$ Brand trust integrality; $\mathrm{BT}_{\text {Bene }}=$ Brand trust benevolence; $\mathrm{OCBI}=$ Online consumer brand identification; $\mathrm{BL}=$ Brand love; $\mathrm{WPP}=$ Willingness to pay a premium price; $\mathrm{ICC}=$ Intention to co-create brand value . 
Figure 2: Summary of the structural model results

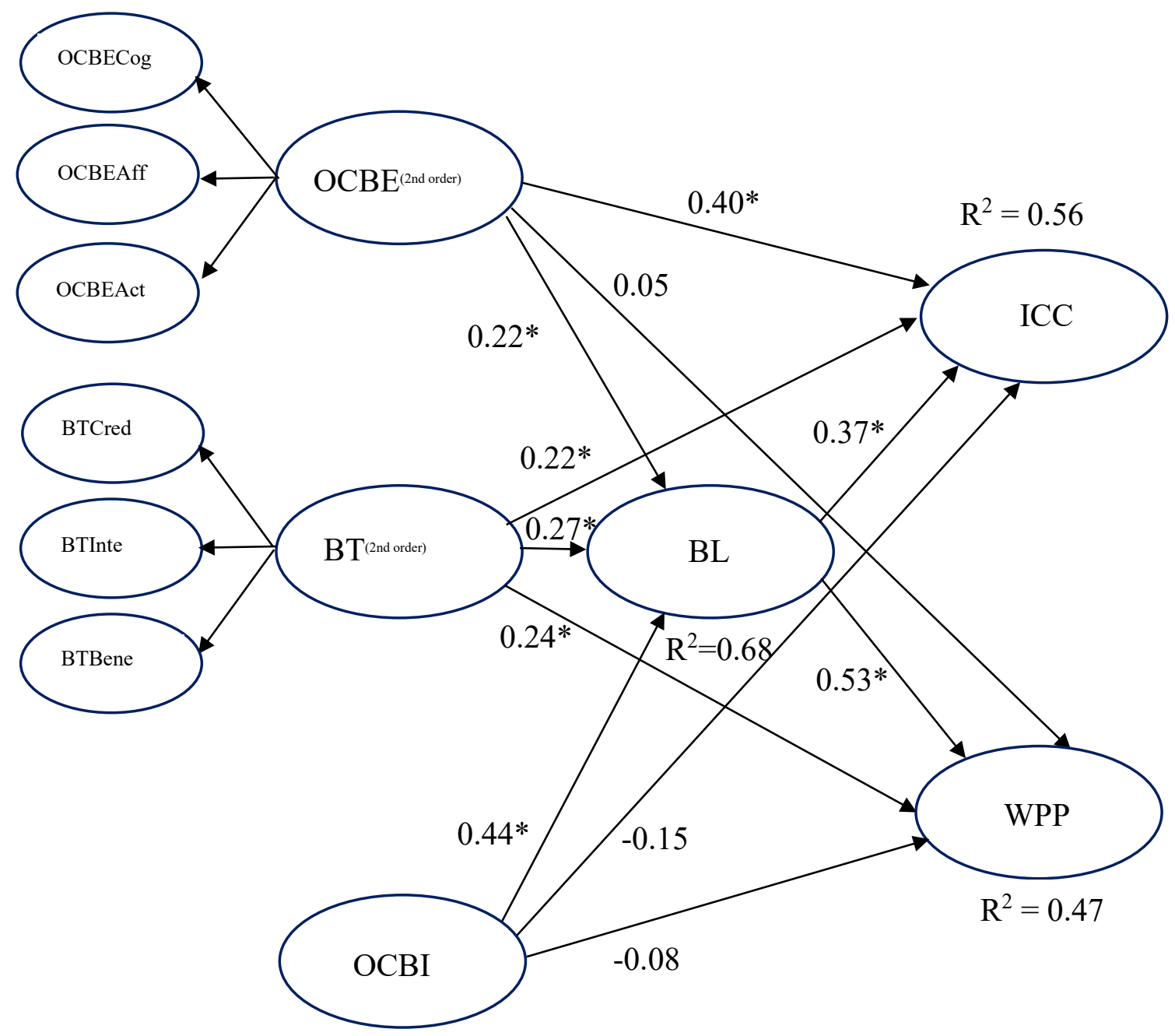

\section{Legend:}

Standardised coefficient. Two-tailed significant testing: $* p \leq 0.01$.

$\mathrm{OCBE}=$ Online consumer brand engagement $\mathrm{OCBE}_{\mathrm{Cog}}=$ Online consumer brand engagement cognitive; $\mathrm{OCBE}_{\text {Aff }}=$ Online consumer brand engagement affective; $\mathrm{OCBE}_{\mathrm{Act}}=$ Online consumer brand engagement active; $\mathrm{BT}=$ Brand trust $\mathrm{BT}_{\text {Cred }}=$ Brand trust credibility; $\mathrm{BT}_{\text {Inte }}=$ Brand trust integrality; $\mathrm{BT}_{\text {Bene }}=$ Brand trust benevolence; $\mathrm{OCBI}=$ Online consumer brand identification; $\mathrm{BL}=$ Brand love; $\mathrm{WPP}=$ Willingness to pay a premium price; ICC $=$ Intention to co-create brand value. 
Table I: Sample profile

\begin{tabular}{|c|c|c|c|}
\hline Criteria & & Number & $\%$ \\
\hline \multicolumn{4}{|l|}{ Gender } \\
\hline Male & & 149 & 44.9 \\
\hline Female & & 183 & 55.1 \\
\hline \multirow[t]{2}{*}{$\mathrm{N} / \mathrm{R}$} & & 0 & 0.0 \\
\hline & Total & 332 & 100 \\
\hline \multicolumn{4}{|l|}{ Age } \\
\hline$<18$ & & 0 & 0.0 \\
\hline $18-22$ & & 111 & 33.5 \\
\hline $23-37$ & & 221 & 66.5 \\
\hline \multirow[t]{2}{*}{$\mathrm{N} / \mathrm{R}$} & & 0 & 0.0 \\
\hline & Total & 332 & 100.0 \\
\hline \multicolumn{4}{|l|}{ Occupation } \\
\hline Student & & 188 & 56.6 \\
\hline Worker & & 132 & 39.8 \\
\hline Student and worker & & 7 & 2.1 \\
\hline Unemployed & & 4 & 1.2 \\
\hline \multirow[t]{2}{*}{$\mathrm{N} / \mathrm{R}$} & & 1 & 0.3 \\
\hline & Total & 332 & 100.0 \\
\hline \multicolumn{4}{|l|}{ Social networks followed } \\
\hline Facebook & & 135 & 40.7 \\
\hline Instagram & & 166 & 50.0 \\
\hline \multirow[t]{2}{*}{ Other (e.g. Twitter, Pinterest) } & & 31 & 9.3 \\
\hline & Total & 332 & 100.0 \\
\hline \multicolumn{4}{|c|}{ Time spent on the social network (per day) } \\
\hline$<1$ hour & & 12 & 3.6 \\
\hline 1- 2 hours & & 48 & 14.5 \\
\hline 2-3 hours & & 82 & 24.7 \\
\hline$>3$ hours & & 187 & 56.3 \\
\hline$>4$ hours & & 3 & 0.9 \\
\hline \multirow{2}{*}{$\mathrm{N} / \mathrm{R}$} & & 0 & 0.0 \\
\hline & Total & 332 & 100.0 \\
\hline
\end{tabular}


Table II: Measurement model estimates

\begin{tabular}{|c|c|c|c|c|}
\hline Construct & Items & $\begin{array}{l}\text { Stand. } \\
\text { loads. }\end{array}$ & t-value & $\overline{\mathbf{R}^{2}}$ \\
\hline \multirow{4}{*}{$\begin{array}{l}\text { OCBE } \\
\left(2^{\text {nd }} \text { order }\right)\end{array}$} & OCBECog & 0.877 & --- & 0.769 \\
\hline & OCBEAff & 0.954 & 12.38 & 0.911 \\
\hline & OCBEAct & 0.791 & 10.14 & 0.625 \\
\hline & $C R=0.908 ; A V E=0.768$ & & & \\
\hline \multirow[t]{4}{*}{ OCBECog } & $\begin{array}{l}\text { When I see the brand's social media activities I get } \\
\text { to think about it. }\end{array}$ & 0.695 & --- & 0.483 \\
\hline & $\begin{array}{l}\text { While I am interacting with the brand on social } \\
\text { media, I think a lot about this brand. }\end{array}$ & 0.857 & 13.93 & 0.734 \\
\hline & $\begin{array}{l}\text { When I am interacting with this brand, I want to } \\
\text { learn more about it. }\end{array}$ & 0.850 & 13.95 & 0.722 \\
\hline & Cronbach alpha $=0.844 ; C R=0.906 ; A V E=0,647$ & & & \\
\hline \multirow[t]{3}{*}{ OCBEAff } & $\begin{array}{l}\text { I feel very positive when I am interacting with this } \\
\text { brand. }\end{array}$ & 0.894 & --- & 0.800 \\
\hline & I feel good when I am interacting with this brand. & 0.925 & 26.01 & 0.855 \\
\hline & $\begin{array}{l}\text { Interacting with this brand makes me feel proud. } \\
\text { Cronbach alpha }=0.919 ; C R=0.921 ; A V E=0.796\end{array}$ & 0.857 & 22.09 & 0.734 \\
\hline \multirow[t]{5}{*}{ OCBEAct } & $\begin{array}{l}\text { I spend a lot of time interacting with this brand, } \\
\text { compared to any other brand. }\end{array}$ & 0.757 & --- & 0.573 \\
\hline & $\begin{array}{l}\text { Whenever I am online on social media, I usually } \\
\text { look for that brand. }\end{array}$ & 0.900 & 17.32 & 0.809 \\
\hline & $\begin{array}{l}\text { I usually interact with this brand, when I log in to } \\
\text { social media. }\end{array}$ & 0.927 & 17.74 & 0.859 \\
\hline & Cronbach alpha $=0.892 ; C R=0.898 ; A V E=0.747$ & & & \\
\hline & Source: Hollebeek et al. (2014) & & & \\
\hline \multirow{4}{*}{$\begin{array}{l}\text { BT }\left(2^{\text {nd }}\right. \\
\text { order })\end{array}$} & BTCred & 0.889 & --- & 0.790 \\
\hline & BTInte & 0.862 & 12.17 & 0.743 \\
\hline & BTBene & 0.884 & 11.41 & 0.782 \\
\hline & $C R=0.910 ; A V E=0.772$ & & & \\
\hline \multirow[t]{3}{*}{ BTCred } & This brand's products make me feel safe. & 0.673 & --- & 0.454 \\
\hline & I trust the quality of this brand's products. & 0.882 & 14.21 & 0.779 \\
\hline & $\begin{array}{l}\text { Buying this brand's products is a guarantee. } \\
\text { Cronbach alpha }=0.853 ; C R=0.874 ; A V E=0.701\end{array}$ & 0.934 & 14.71 & 0.872 \\
\hline \multirow[t]{2}{*}{ BTInte } & This brand is sincere with consumers. & 0.981 & --- & 0.962 \\
\hline & $\begin{array}{l}\text { This brand is honest with its customers. } \\
\text { Cronbach alpha }=0.968 ; C R=0.968 ; A V E=0.938\end{array}$ & 0.956 & 39.77 & 0.914 \\
\hline \multirow[t]{4}{*}{ BTBene } & $\begin{array}{l}\text { I think this brand improves continuously its } \\
\text { responses to customers' needs. }\end{array}$ & 0.875 & 21.79 & 0.765 \\
\hline & $\begin{array}{l}\text { I think this brand renews its products to take into } \\
\text { account advances in research. }\end{array}$ & 0,927 & --- & 0.860 \\
\hline & Cronbach alpha $=0.895 ; C R=0.896 ; A V E=0.812$ & & & \\
\hline & Source: Gurviez and Korchia (2002) & & & \\
\hline
\end{tabular}


Table II: Measurement model estimates (cont.)

\begin{tabular}{|c|c|c|c|c|}
\hline Construct & Items & $\begin{array}{l}\text { Stand. } \\
\text { loads. }\end{array}$ & t-value & $\mathbf{R}^{2}$ \\
\hline \multirow[t]{6}{*}{ OCBI } & I feel a strong sense of belonging to this brand. & 0.784 & --- & 0.615 \\
\hline & I identify strongly with this brand. & 0.794 & 15.93 & 0.638 \\
\hline & This Brand is like a part of me. & 0.876 & 17.96 & 0.768 \\
\hline & $\begin{array}{l}\text { This Brand has a great deal of personal meaning to } \\
\text { me. }\end{array}$ & 0.913 & 18.91 & 0.833 \\
\hline & Cronbach alpha $=0.907 ; C R=0.908 ; A V E=0,712$ & & & \\
\hline & Source: Stokburger-Sauer et al. (2012). & & & \\
\hline \multirow[t]{6}{*}{ BL } & This brand makes me very happy. & 0.902 & --- & 0.814 \\
\hline & I love this brand! & 0.892 & 24.59 & 0.796 \\
\hline & This brand is a pure delight. & 0.839 & 21.46 & 0.703 \\
\hline & I'm very attached to this brand. & 0.859 & 22.59 & 0.738 \\
\hline & Cronbach alpha $=0,927 ; C R=0.928 ; A V E=0.763$ & & & \\
\hline & Source: Adapted from Carroll and Ahuvia (2006) & & & \\
\hline \multirow[t]{4}{*}{ WPP } & $\begin{array}{l}\text { I would be willing to pay a higher price for this } \\
\text { brand over other similar brands. }\end{array}$ & 0.820 & --- & 0.673 \\
\hline & $\begin{array}{l}\text { I prefer to shop this brand even if another brand } \\
\text { advertises some deal. }\end{array}$ & 0.835 & 12.74 & 0.698 \\
\hline & Cronbach alpha $=0.813 ; C R=0.813 ; A V E=0,685$ & & & \\
\hline & Source: Park and Kim (2014) & & & \\
\hline \multirow[t]{6}{*}{ ICC } & $\begin{array}{l}\text { I am willing to provide my experiences and } \\
\text { suggestions when my friends on my favorite social } \\
\text { networking site want my advice on buying } \\
\text { something from a brand. }\end{array}$ & 0.778 & --- & 0.606 \\
\hline & $\begin{array}{l}\text { I am willing to buy the products of a brand } \\
\text { recommended by my friends on my favorite social } \\
\text { networking site. }\end{array}$ & 0.894 & 17.07 & 0.799 \\
\hline & $\begin{array}{l}\text { I will consider the shopping experiences of my } \\
\text { friends on my favorite social networking site when }\end{array}$ & 0.844 & 16.21 & 0.712 \\
\hline & I want to shop a brand. & & & \\
\hline & Cronbach alpha $=0.869 ; C R=0.878 ; A V E=0,706$ & & & \\
\hline & Source: Tajvidi et al. (2017) (In press). & & & \\
\hline
\end{tabular}

Notes: Stand. loads $=$ Standardised loadings. $\mathrm{CR}=$ Composite reliability; AVE $=$ Average variance extracted.

$\mathrm{OCBE}=$ Online consumer brand engagement; $\mathrm{OCBE}_{\mathrm{Cog}}=$ Online consumer brand engagement cognitive; $\mathrm{OCBE}_{\mathrm{Aff}}=$ Online consumer brand engagement affective; $\mathrm{OCBE}_{\mathrm{Act}}=$ Online consumer brand engagement active; $\mathrm{BT}=$ Brand trust $\mathrm{BT}_{\text {Cred }}=$ Brand trust credibility; $\mathrm{BT}_{\text {Inte }}=$ Brand trust integrality; $\mathrm{BT}_{\mathrm{Bene}}=\mathrm{Brand}$ trust benevolence; $\mathrm{OCBI}=$ Online consumer brand identification; $\mathrm{BL}=$ Brand love; WPP $=$ Willingness to pay a premium price; $\mathrm{ICC}=$ Intention to co-create brand value.

Model global fit: Chi-square $(\chi 2)=839.67 ; d f=356$; goodness of fit index $(\mathrm{GFI})=0.845$; incremental fit index $(\mathrm{IFI})=0.944$; Tucker-Lewis index $(\mathrm{TLI})=0.936$; comparative fit index $(\mathrm{CFI})=0.944$; root mean square error approximation $($ RMSEA) $=0.064$. 
Table III: Discriminant validity analysis

\begin{tabular}{lcccccc}
\hline & OCBE $\left(2^{\text {nd }}\right.$ order $)$ & $\mathrm{BT}\left(2^{\text {nd }}\right.$ order $)$ & OCBI & BL & WPP & ICC \\
\hline OCBE $\left(2^{\text {nd }}\right.$ order $)$ & $\mathbf{0 . 7 6 8}$ & & & & & \\
BT $\left(2^{\text {nd }}\right.$ order $)$ & 0.262 & $\mathbf{0 . 7 7 2}$ & & & & \\
OCBI & 0.610 & 0.419 & $\mathbf{0 . 7 1 2}$ & & & \\
BL & 0.491 & 0.445 & 0.618 & $\mathbf{0 . 7 6 3}$ & & \\
WPP & 0.224 & 0.318 & 0.280 & 0.433 & $\mathbf{0 . 6 8 5}$ & \\
ICC & 0.436 & 0.329 & 0.362 & 0.465 & 0.299 & $\mathbf{0 . 7 0 6}$ \\
\hline
\end{tabular}

Note: Diagonal entries are average variance extracted and the body of table are the estimated correlation square OCBE $=$ Online consumer brand engagement; $\mathrm{BT}=$ Brand trust; $\mathrm{OCBI}=$ Online consumer brand identification; $\mathrm{BL}=$ Brand love; WPP $=$ Willingness to pay a premium price; $\mathrm{ICC}=$ Intention to co-create brand value. 
Table IV: Structural model results

\begin{tabular}{lccc}
\hline Path & Stand. coeff & t-value & $\begin{array}{c}\text { hypotheses } \\
\text { testing }\end{array}$ \\
\hline $\mathrm{OCBE}\left(2^{\text {nd }}\right.$ order $) \longrightarrow \mathrm{BL}$ & 0.219 & $3.11^{*}$ & $\mathrm{H}_{1}(+): \mathrm{S}$ \\
$\mathrm{OCBE}\left(2^{\text {nd }}\right.$ order $) \longrightarrow \mathrm{ICC}$ & 0.403 & $4.45^{*}$ & $\mathrm{H}_{2}(+): \mathrm{S}$ \\
$\mathrm{OCBE}\left(2^{\text {nd }}\right.$ order $) \longrightarrow \mathrm{WPP}$ & 0.045 & 0.47 & $\mathrm{H}_{3}(+): \mathrm{NS}$ \\
$\mathrm{BT}\left(2^{\text {nd }}\right.$ order $) \longrightarrow \mathrm{BL}$ & 0.270 & $4.74^{*}$ & $\mathrm{H}_{4}(+): \mathrm{S}$ \\
$\mathrm{BT}\left(2^{\text {nd }}\right.$ order $) \longrightarrow \mathrm{ICC}$ & 0.217 & $3.08^{*}$ & $\mathrm{H}_{5}(+): \mathrm{S}$ \\
$\mathrm{BT}\left(2^{\text {nd }}\right.$ order $) \longrightarrow \mathrm{WPP}$ & 0.241 & $3.00^{*}$ & $\mathrm{H}_{6}(+): \mathrm{S}$ \\
$\mathrm{OCBI} \longrightarrow \mathrm{BCC}$ & 0.440 & $5.40^{*}$ & $\mathrm{H}_{7}(+): \mathrm{S}$ \\
$\mathrm{OCBI} \longrightarrow \mathrm{WPP}$ & -0.145 & -1.42 & $\mathrm{H}_{8}(+): \mathrm{NS}$ \\
$\mathrm{OCBI} \longrightarrow \mathrm{ICC}$ & -0.078 & -0.67 & $\mathrm{H}_{9}(+): \mathrm{NS}$ \\
$\mathrm{BL} \longrightarrow \mathrm{WPP}$ & 0.373 & $4.18^{*}$ & $\mathrm{H}_{10}(+): \mathrm{S}$ \\
$\mathrm{BL} \longrightarrow \mathrm{HL}$ & 0.529 & $5.12^{*}$ & $\mathrm{H}_{11}(+): \mathrm{S}$ \\
\hline
\end{tabular}

Notes: Stand. coeff. $=$ standardised coefficient; two-tailed significant testing: ${ }^{*} p \leq 0.01 . \mathrm{S}=$ Supported; $\mathrm{NS}=$ Not supported; OCBE $=$ Online consumer brand engagement; $\mathrm{BT}=$ Brand trust; $\mathrm{OCBI}=$ Online consumer brand identification; $\mathrm{BL}=$ Brand love; WPP $=$ Willingness to pay a premium price; $\mathrm{ICC}=$ Intention to co-create brand value.

Model global fit: Chi-square $(\chi 2)=842.87, d f=357$, goodness of fit index $(\mathrm{GFI})=0.844$; incremental fit index $(\mathrm{IFI})=0.944$, Tucker-Lewis index $(\mathrm{TLI})=0.936$, comparative fit index $(\mathrm{CFI})=0.944$; root mean square error approximation $($ RMSEA $)=0.064$. 
Appendix: Brands followed on social media, by category

\begin{tabular}{|l|l|c|}
\hline Category & \multicolumn{1}{|c|}{ Brands mentioned } & Percentage \\
\hline Fashion clothing & Fred Perry, H\&M, La Redoute, Leon, Scotch \& Soda & $28 \%$ \\
\hline $\begin{array}{l}\text { Sports shoes \& } \\
\text { clothing }\end{array}$ & Adidas, Gymshark, Nike, Puma & $16 \%$ \\
\hline Technology & Apple, Canon, GoPro, Skullcandy, Sony, Vodafone & $9 \%$ \\
\hline Cosmetics & Body Shop, L'Oreal, Mac cosmetics, Sephora & $9 \%$ \\
\hline Entertainment & Disney, Marvel, Netflix, Nintendo & $8 \%$ \\
\hline Cars & Audi, BMW, Ferrari, Land Rover, Mercedes, TESLA & $5 \%$ \\
\hline Food & Danone, Nestle, Origens Bio & $4 \%$ \\
\hline Football & Benfica, NGA Soccer, Sporting Lisbon & $3 \%$ \\
\hline Fashion shoes & Converse, New Balance, Sketchers & $2 \%$ \\
\hline Luxury goods & Dior, Gucci, Michael Kors, Saint Laurent & $2 \%$ \\
\hline Soft drinks & Coca-Cola, Red Bull & $2 \%$ \\
\hline Jewelry & Pandora, Tous, Nelo & $2 \%$ \\
\hline Alcohol & Guinness, Sagres, Super Bock & $1 \%$ \\
\hline Airlines & Boeing, Lufthansa, Ryanair & $7 \%$ \\
\hline Fast food & McDonalds, Wendys & \\
\hline Other & Miscellaneous brands, including categories: \\
\hline
\end{tabular}

